\title{
PENGARUH EDUKASI GIZI DENGAN METODE CERAMAH BERBASIS BAHASA ISYARAT INDONESIA (BISINDO) DAN BOOKLET TERHADAP PENGETAHUAN, SIKAP DAN PRAKTIK GIZI PADA REMAJA TULI SLB DI SEMARANG
}

\author{
Duena Firsta Sridiasti Ayumar, Ani Margawati*, Hartanti Sandi Wijayanti \\ Departemen Ilmu Gizi, Fakultas Kedokteran, Universitas Diponegoro \\ Jl. Prof. Sudarto SH, Tembalang, Semarang, Jawa Tengah 50275, Indonesia \\ "Penulis Penanggungjawab. E-mail: animargawati@gmail.com
}

\begin{abstract}
Background : Around 73,6\% Deaf adolescents on SLB Negeri Semarang do not meet fruit and vegetable intake recommendation. Nutrition education is needed to improve nutrition knowledge and attitude which lead to behavior change. Lecture and booklet are popular nutrition education method which often used. Despite popularity, both methods have each limitation to be applied in Deaf. The aim of the study is to determine Indonesian sign languagebased lecture and booklet education's impact on nutrition knowledge, attitude and practice among deaf adolescent students in Semarang.

Methods : This Quasi Experimental research with pre-post test group design study was involving 27 Deaf students. Subjects are student on SMPLB and SMALB in Semarang divided into booklet and lecture group. Nutrition education is given by Hearing people accompanied by sign language intrepeter.

Result : There is no significant difference of knowledge $(p=0,359)$, attitude $(p=0,063)$, and fruit and vegetable consumption practice $(p=0,692)$ after nutrition education program between two groups. Median of knowledge insignificantly increase. In spite of no difference trend, nutritional lecture group show better result in every dependent variables but fruit and vegetable consumption practice.

Conclusion : Indonesian sign language-based lecture and booklet education has no significant impact on nutrition knowledge, attitude and fruit and vegetable consumption practice among deaf adolescent students in Semarang.
\end{abstract}

Keywords : Nutrition Education; Deaf; Lecture; Booklet; Sign Language

\begin{abstract}
ABSTRAK
Latar Belakang : Sebanyak 73,6\% siswa remaja Tuli SLB Negeri Semarang tidak mengonsumsi sayur dan buah sesuai anjuran. Edukasi gizi dibutuhkan untuk meningkatkan pengetahuan dan sikap gizi, dimana keduanya memiliki peran dalam perubahan perilaku gizi remaja. Metode ini memanfaatkan indera Tuli yang bekerja dengan optimal yaitu penglihatan. Akan tetapi Tuli memiliki perbendaharaan kata yang cukup terbatas. Metode ceramah yang diterapkan di sekolah (lip-reading) diharapkan meningkatkan kemampuan Tuli menyesuaikan diri dalam kelompok sosial. Namun, penelitian sebelumnya menunjukkan bahwa lip-reading akan lebih optimal apabila dibersamai dengan penggunaan isyarat. Tujuan penelitian ini adalah mengetahui pengaruh edukasi gizi dengan metode ceramah berbasis BISINDO dan booklet terhadap pengetahuan, sikap dan praktik gizi pada remaja Tuli SLB di Semarang.

Metode : Jenis penelitian ini adalah Quasi Experimental dengan rancangan pre-post test group design. Subjek penelitian adalah 27 siswa SMP dan SMA LB di Semarang, yang dibagi menjadi kelompok booklet dan ceramah. Edukasi gizi diberikan oleh orang Dengar dengan bantuan juru bahasa isyarat.

Hasil : Tidak ada beda pengetahuan $(p=0,359)$, sikap $(p=0,063)$, dan praktik konsumsi sayur dan buah $(p=0,692)$ antara kedua kelompok perlakuan setelah pemberian edukasi gizi. Median nilai pengetahuan mengalami peningkatan. Walaupun kecenderungan hasil penelitian menunjukkan tidak ada perbedaan, nilai kelompok ceramah lebih baik dibandingkan kelompok booklet kecuali pada praktik konsumsi sayur dan buah.

Simpulan : Tidak ada pengaruh edukasi gizi dengan metode ceramah berbasis bahasa isyarat Indonesia (BISINDO) dan booklet terhadap pengetahuan, sikap dan praktik konsumsi sayur dan buah pada remaja Tuli SLB di Semarang
\end{abstract}

Kata kunci : Edukasi Gizi; Tuli; Ceramah; Booklet; Bahasa Isyarat

\section{PENDAHULUAN}

Periode remaja merupakan rentang waktu yang kritis dan penting terkait pemenuhan gizi. ${ }^{1}$ Riset kesehatan dasar tahun 2018 menunjukkan bahwa $24,7 \%$ remaja usia $13-15$ tahun dan $21,6 \%$ remaja usia 16-18 tahun mengalami malnutrisi. ${ }^{2}$
Salah satu perilaku berisiko pada pelajar SMP dan SMA dengan prevalensi paling besar adalah kebiasaan konsumsi sayur dan buah yang kurang. ${ }^{3}$ Temuan serupa terjadi pada siswa berkebutuhan khusus pada sekolah luar biasa tipe B (SLB) di kota Semarang. Penelitian pendahuluan yang dilakukan 
pada bulan September 2018 menunjukkan sebanyak $73,6 \%$ siswa SMP dan SMA di SLB B Negeri Semarang mengonsumsi sayur dan buah kurang dari anjuran yang tertulis dalam Pedoman Gizi Seimbang. Penelitian di Jimbaran pada tahun 2014 menyebutkan, bahwa 20\% siswa SLB B berstatus gizi kurus. Ini menunjukkan bahwa Tuli memiliki risiko yang sama terhadap malnutrisi. ${ }^{4}$

Perubahan perilaku gizi pada remaja dipengaruhi oleh banyak faktor, diantaranya pengetahuan gizi dan sikap gizi. Sikap dan pengetahuan gizi dapat ditingkatkan dengan stimulus berupa edukasi gizi. ${ }^{5}$ Hasil penelitian sebelumnya menyebutkan, edukasi gizi secara signifikan dapat meningkatkan rerata pengetahuan dan sikap gizi pada kelompok remaja overweight yang diberikan edukasi dengan metode ceramah dan metode booklet. ${ }^{6}$ Penelitian lain menyebutkan, pemberian edukasi gizi mampu meningkatkan perubahan pola makan, melalui penilaian kualitas diet, pada remaja usia 16-19 tahun. $^{7}$

Metode ceramah dan booklet merupakan dua diantara berbagai metode edukasi gizi yang sering digunakan dan dapat diaplikasikan pada kelompok Tuli. Pemberian informasi melalui tulisan adalah hal yang umum diterapakan pada Tuli, sepertinya halnya pada metode booklet. Metode ini memanfaatkan indera Tuli yang bekerja dengan optimal yaitu penglihatan. Akan tetapi Tuli memiliki perbendaharaan kata yang cukup terbatas, ${ }^{8}$ sehingga ada kemungkinan kesulitan dalam memahami isi bacaan seperti pada booklet. ${ }^{9}$ Metode ceramah hadir sebagai metode sehari-hari yang digunakan guru di sekolah. Siswa Tuli, melalui metode ini, diharapkan mampu menyesuaikan diri dalam kelompok sosial dengan terbiasa membaca gerakan bibir lawan bicara (lip-reading). Namun, penelitian sebelumnya menunjukkan bahwa lip-reading akan lebih optimal apabila dibersamai dengan penggunaan isyarat. Bahasa isyarat tidak hanya bicara mengenai simbol, tapi juga ekspresi dan emosi. Umumnya, penggunaan metode ceramah atau booklet dalam pemberian edukasi tidak menunjukkan adanya perbedaan peningkatan pengetahuan yang signifikan antara kedua kelompok..$^{6,10}$

Tuli sebagai sebuah kelompok budaya masih sering menemui kesulitan dalam akses pelayanan kesehatan. Penelitian sebelumnya menyebutkan $44 \%$ Tuli merasa kesulitan dalam berinteraksi dengan petugas kesehatan. ${ }^{11}$ Sebanyak $80 \%$ Tuli ingin berkomunikasi dengan petugas kesehatannya menggunakan bahasa isyarat, tapi hanya 3 dari 10 yang mendapatkan hal tersebut. ${ }^{12}$ Bahasa isyarat menjadi salah satu usaha pemenuhan hak Tuli untuk mampu berkomunikasi dan memperoleh informasi yang mudah diakses, salah satunya informasi kesehatan dan gizi. Akses informasi gizi yang terjamin menjadi penting untuk meningkatkan pengetahuan Tuli sehingga terhindar dari masalah gizi.

Perlu dikaji lebih lanjut terkait kelaikan metode ceramah maupun booklet sebagai edukasi gizi yang efektif untuk Tuli. Berdasarkan latar belakang tersebut, peneliti tertarik untuk mengkaji pengaruh edukasi gizi dengan metode ceramah berbasis bahasa isyarat Indonesia (BISINDO) dan booklet terhadap pengetahuan, sikap dan praktik gizi remaja Tuli SLB di Semarang. Penelitian ini bertujuan untuk mengetahui pengaruh edukasi gizi dengan metode ceramah berbasis bahasa isyarat Indonesia (BISINDO) dan booklet terhadap pengetahuan, sikap dan praktik konsumsi sayur dan buah pada remaja Tuli SLB di Semarang.

\section{METODE}

Penelitian ini termasuk dalam ruang lingkup keilmuan gizi masyarakat. Jenis penelitian yang digunakan adalah penelitian Quasi Experimental dengan rancangan pre-post test group design. Populasi target penelitian ini adalah remaja Tuli tingkat SMP dan SMA di kota Semarang. Penelitian dilaksanakan pada bulan Februari 2019 di SLB Negeri Semarang dan SLB Widya Bhakti Semarang.

Besar sampel minimal adalah 22 subjek dibagi menjadi dua kelompok perlakuan, termasuk antisipasi drop out sebesar 10\%. Pengambilan sampel dilakukan dengan teknik consecutive sampling sesuai dengan kriteria inklusi; bisa membaca dan menulis, dapat berkomunikasi menggunakan bahasa isyarat Indonesia (BISINDO), berada di jenjang pendidikan SMP atau SMA selama pengambilan data, bersedia menjadi subjek penelitian yang dibuktikan dengan penandatanganan informed consent dan mendapatkan izin dari sekolah untuk ikut dalam penelitian. Kriteria eksklusi pada penelitian ini, yaitu mengundurkan diri sebelum penelitian selesai, tidak mengikuti tahapan penelitian secara penuh dan pindah sekolah.

Pengambilan data di SLB Negeri Semarang, sejumlah 19 subjek menandatangani informed consent dan memenuhi kriteria inklusi. Terdapat 3 subjek yang drop out karena tidak mengikuti sesi edukasi ( 2 subjek) dan tidak mengikuti post-test (1 subjek). Penelitian dilanjutkan di SLB Widya Bhakti, 11 subjek menandatangani informed consent dan memenuhi kriteria inklusi. Semua diikutsertakan dalam penelitian dengan alasan etis (sudah hadir) dan sebagai antisipasi drop out. Besar sampel terakhir adalah 27 subjek penelitian, yang dibagi menjadi 14 subjek penelitian kelompok booklet dan 13 subjek penelitian kelompok ceramah. 
Variabel independen dalam penelitian ini adalah metode edukasi gizi, yaitu metode ceramah berbasis BISINDO dan Booklet. Penelitian dilaksanakan dalam 2 pertemuan. Pertemuan pertama untuk mengambil data subjek penelitian, pre-test pengetahuan, sikap dan praktik konsumsi sayur dan buah, kemudian diberi jeda isitrahat. Setelah istirahat, dilanjutkan dengan edukasi gizi dengan materi terkait konsumsi sayur dan buah. Edukasi diberikan selama 40 menit dalam satu kali pertemuan karena keterbatasan izin dari pihak sekolah. Pertemuan kedua dilaksanakan satu minggu setelah pertemuan pertama digunakan untuk evaluasi edukasi gizi, yaitu pengambilan post-test pengetahuan, sikap dan praktik konsumsi sayur dan buah. Evaluasi edukasi gizi dilaksanakan satu kali.

Edukasi gizi diberikan oleh seorang pemateri dan juru bahasa isyarat. Pemateri adalah mahasiswa gizi Dengar yang menyampaikan materi edukasi gizi secara oral. Juru bahasa isyarat berasal orang Dengar yang menerjemahkan perkataan pemateri ke dalam bahasa Isyarat Indonesia (BISINDO).

Kelompok pertama diberikan edukasi gizi dengan metode ceramah berbasis bahasa isyarat Indonesia (BISINDO). Pemateri berdiri pada posisi dimana suara pemateri terjangkau oleh juru bahasa isyarat. Pemateri membawakan materi sebagaimana menghadapi peserta orang Dengar dengan dibantu slide powerpoint selama 20 menit. Waktu tanya jawab diberikan selama 10 menit. Subjek penelitian diberikan kesempatan untuk bertanya dalam bahasa isyarat, kemudian juru bahasa isyarat menyampaikan ke pemateri. Pertanyaan dijawab dengan skema komunikasi yang sama. Terakhir diberikan waktu mengulas materi selama 10 menit, mengulas materi dilakukan dengan memberikan pertanyaan pada subjek penelitian untuk dijawab bersama-sama dan memberikan kesempatan bertanya terakhir.

Kelompok kedua diberikan perlakuan berupa edukasi gizi dengan metode booklet . Subjek penelitian diberi booklet, kertas catatan dan pulpen. Juru bahasa isyarat memberikan penjelasan umum terkait booklet. Subjek penelitian dipersilakan menuliskan semua hal yang mereka tidak ketahui untuk kemudian ditanyakan. Selama proses membaca (20 menit), subjek diminta membaca pelan-pelan dari awal hingga akhir dan dibiarkan membaca secara mandiri dengan pengawasan mahasiswa gizi dan juru bahasa isyarat. Waktu tanya jawab dilakukan selama 10 menit menggunakan bahasa isyarat. Sepuluh menit terakhir digunakan untuk membaca ulang, memberikan kesempatan bertanya terakhir dan penjelasan lembar kerja "Buku Harian Sayur dan Buah" pada booklet. Subjek penelitian diminta untuk menuliskan berapa kali makan sayur dan buah setiap hari selama satu minggu berikutnya dengan tujuan utama untuk menarik subjek penelitian membaca ulang booklet. Booklet dibawa pulang oleh subjek penelitian.

Variabel dependen dalam penelitian ini adalah pengetahuan, sikap dan praktik konsumsi sayur dan buah. Variabel perancu dalam penelitian ini adalah usia, jenis kelamin, tingkat pendidikan, pengalaman edukasi gizi sebelumnya, pengalaman negatif terkait konsumsi sayur dan buah, pengaruh orang tua dan guru, pengaruh teman sebaya, dan sumber media informasi.

Data pengetahuan diperoleh dari kuesioner pengetahuan yang terdiri atas 6 pertanyaan pilihan ganda. Jawaban benar dikonversi dalam rentang nilai 0-100 sebagai nilai pengetahuan. Nilai pengetahuan dikategorikan dalam 3 kategori, yaitu kategori kurang $(<60)$, kategori cukup $(60-80)$ dan kategori baik $(>80){ }^{6}$ Data sikap diperoleh dari kuesioner sikap yang terdiri atas 10 pernyataan. Masingmasing pernyataan dilengkapi dengan 5 pilihan jawaban "sangat tidak setuju", "tidak setuju", "raguragu", "setuju", dan "sangat setuju", dengan rentang skor 1-5. Total skor kemudian dikonversi dalam rentang nilai 0-100 sebagai nilai sikap. Nilai sikap dikategorikan menjadi 3 kategori, yaitu kategori kurang $(<60)$, kategori cukup (60-79) dan kategori baik $(\geq 80){ }^{6}$

Data praktik konsumsi sayur dan buah diperoleh dari kuesioner konsumsi sayur dan buah dalam satu minggu terakhir. Jika dalam satu hari subjek makan sayur atau buah maka mendapatkan skor 1, skor maksimal pada kuesioner ini adalah 7 . Skor konsumsi sayur dan skor konsumsi buah masing-masing dikonversi dalam rentang nilai 0 100 , kemudian diambil reratanya sebagai nilai praktik konsumsi sayur dan buah. Nilai praktik konsumsi sayur dan buah dibagi menjadi 2 kategori, yaitu kategori kategori cukup (setiap hari mengonsumsi buah dan sayur minimal 1 kali) dan kurang (tidak setiap hari mengonsumsi sayur dan buah).

Data variabel perancu diperoleh dari kuesioner subjek penelitian. Data usia kemudian dikelompokkan berdasarkan tahapan remaja menurut WHO. Pengalaman edukasi, paparan media informasi, pengalaman negatif, pengaruh orang tua dan guru, dan pengaruh teman sebaya terkait konsumsi sayur dan buah dibagi berdasarkan jawaban "Ya" dan "Tidak". Data status gizi ditampilkan sebagai karakteristik umum subjek penelitian, dikelompokkan berdasarkan IMT/U, kecuali untuk subjek usia >19 tahun menggunakan IMT.

Analisis data penelitian ini menggunakan perangkat lunak analisis data. Analisis univariat 
digunakan untuk mendapatkan nilai rerata, median, nilai minimal dan nilai maksimal. Analisis bivariat bertujuan untuk melihat pengaruh metode edukasi gizi dengan pengetahuan gizi, sikap dan praktik konsumsi sayur dan buah. Analisis bivariat juga digunakan untuk menunjukkan perbedaan karakteristik variabel perancu pada kedua kelompok perlakuan. Normalitas data diuji dengan uji Sappiro wilk. Data yang berdistribusi normal dianalisis menggunakan uji parametrik, yaitu Paired t-test dan independent t-test. Data yang tidak berdistribusi normal, dianalisis menggunakan uji non-parametrik, yaitu Wilcoxon test dan Mann-Whitney test. Analisis bivariat dilakukan dengan menggunakan derajat kepercayaan sebesar $95 \%$.

\section{HASIL}

Gambaran umum karakteristik subjek penelitian terdiri atas usia, jenis kelamin, tingkat pendidikan dan status gizi ditampilkan pada Tabel 1 .

Tabel 1 Gambaran Karakteristik Umum Subjek Peneltian Sebelum Edukasi terkait Konsumsi Sayur dan Buah

\begin{tabular}{|c|c|c|c|c|c|}
\hline \multirow{2}{*}{ Karakteristik } & \multicolumn{2}{|c|}{ Booklet $(n=14)$} & \multicolumn{2}{|c|}{ Ceramah $(n=13)$} & \multirow[t]{2}{*}{$p$} \\
\hline & Frekuensi & $\%$ & Frekuensi & $\%$ & \\
\hline \multicolumn{6}{|l|}{ Usia } \\
\hline Remaja Awal (10 - 14 tahun) & 1 & $7,14 \%$ & 0 & $0,00 \%$ & \multirow{3}{*}{$0,429^{a}$} \\
\hline Remaja Tengah (>14 - 17 tahun) & 10 & $71,43 \%$ & 9 & $69,23 \%$ & \\
\hline Remaja Akhir (>17 - 21 tahun) & 3 & $21,43 \%$ & 4 & $30,77 \%$ & \\
\hline \multicolumn{6}{|l|}{ Jenis Kelamin } \\
\hline Laki-laki & 7 & $50,00 \%$ & 9 & $69,23 \%$ & \multirow{2}{*}{$0,319^{\mathrm{a}}$} \\
\hline Perempuan & 7 & $50,00 \%$ & 4 & $30,77 \%$ & \\
\hline \multicolumn{6}{|l|}{ Tingkat Pendidikan } \\
\hline SMP & 9 & $64,29 \%$ & 7 & $53,85 \%$ & \multirow{2}{*}{$0,588^{a}$} \\
\hline SMA & 5 & $35,71 \%$ & 6 & $46,15 \%$ & \\
\hline \multicolumn{6}{|l|}{ Status Gizi } \\
\hline Kurus & 2 & $14,29 \%$ & 3 & $23,08 \%$ & \multirow{4}{*}{$0,249^{\mathrm{a}}$} \\
\hline Normal & 7 & $50,00 \%$ & 8 & $61,54 \%$ & \\
\hline Gemuk & 2 & $14,29 \%$ & 1 & $7,69 \%$ & \\
\hline Obesitas & 3 & $21,43 \%$ & 1 & $7,69 \%$ & \\
\hline \multicolumn{6}{|l|}{ Pengalaman Edukasi } \\
\hline Pernah & 13 & $92,86 \%$ & 11 & $84,62 \%$ & \multirow{2}{*}{$0,504^{\mathrm{a}}$} \\
\hline Tidak Pernah & 1 & $7,14 \%$ & 2 & $15,38 \%$ & \\
\hline \multicolumn{6}{|l|}{ Paparan Media Informasi } \\
\hline Terpapar & 13 & $92,86 \%$ & 12 & $92,31 \%$ & \multirow{2}{*}{$0,957^{\mathrm{a}}$} \\
\hline Tidak Terpapar & 1 & $7,14 \%$ & 1 & $7,69 \%$ & \\
\hline \multicolumn{6}{|l|}{ Pengalaman Negatif } \\
\hline Pernah & 9 & $64,29 \%$ & 8 & $61,54 \%$ & \multirow{2}{*}{$0,885^{\mathrm{a}}$} \\
\hline Tidak Pernah & 5 & $35,71 \%$ & 5 & $38,46 \%$ & \\
\hline \multicolumn{6}{|l|}{ Pengaruh Orang Tua dan Guru } \\
\hline Ada & 10 & $71,43 \%$ & 9 & $69,23 \%$ & \multirow{2}{*}{$0,902^{\mathrm{a}}$} \\
\hline Tidak ada & 4 & $28,57 \%$ & 4 & $30,77 \%$ & \\
\hline \multicolumn{6}{|l|}{ Pengaruh Teman Sebaya } \\
\hline Ada & 9 & $64,29 \%$ & 11 & $84,62 \%$ & \multirow[t]{2}{*}{$0,237^{\mathrm{a}}$} \\
\hline Tidak ada & 5 & $35,71 \%$ & 2 & $15,38 \%$ & \\
\hline
\end{tabular}

Tabel 1 menunjukkan tidak ada beda karakteristik umum pada kedua kelompok perlakuan sebelum dilakukan edukasi, yang meliputi usia $(p=0,429)$, jenis kelamin $(p=0,319)$, tingkat pendidikan $(p=0,588)$, dan status gizi $(p=0,249)$. Mayoritas subjek penelitian pada kedua kelompok berusia 14 hingga 17 tahun atau sedang berada pada periode remaja tengah $(71,43 \% ; 69,23 \%)$. Gambaran status gizi subjek penelitian berdasarkan IMT/U menunjukkan sebagian responden pada kedua kelompok memiliki status gizi normal (50,00\%; $61,54 \%$ ), sisanya mengalami malnutrisi dengan prevalensi gizi lebih lebih besar dibandingkan gizi kurang.

Tabel 1 juga menunjukkan tidak terdapat perbedaan variabel pengalaman edukasi sayur dan buah $(p=0,504)$, paparan media informasi tentang konsumsi sayur dan buah $(p=0,957)$ pengalaman negatif saat konsumsi sayur dan buah $(p=0,885)$, pengaruh orang tua dan guru $(p=0,902)$, dan pengaruh teman sebaya $(p=0,237)$ pada kedua kelompok perlakuan sebelum edukasi. Hampir semua subjek penelitian pernah mendapatkan edukasi tentang sayur dan buah $(>84,62 \%)$ dan 
terpapar media informasi terkait sayur dan buah $(>92,31 \%)$. Semua subjek penelitian mendapatkan arahan untuk makan sayur dan buah dari orang tua, namun tidak semua orang tua memberikan contoh untuk konsumsi sayur dan buah. Persentase subjek penelitian yang mendapatkan pengaruh sosial dari teman sebaya pada kelompok ceramah $(84,62 \%)$ lebih besar dibandingkan kelompok booklet $(64,29 \%)$.

Tabel 2 Perbedaan Pengetahuan, Sikap dan Praktik Konsumsi Sayur dan Buah Sebelum dan Sesudah Edukasi

\begin{tabular}{|c|c|c|c|c|c|}
\hline \multirow{2}{*}{ Variabel } & \multicolumn{2}{|c|}{ Booklet $(\mathrm{n}=14)$} & \multicolumn{2}{|c|}{ Ceramah $(n=13)$} & \multirow{2}{*}{$p$} \\
\hline & Median (Min; Max) & Rerata \pm SD & Median (Min; Max) & Rerata \pm SD & \\
\hline \multicolumn{6}{|l|}{ Pengetahuan } \\
\hline Pre & $41,66(16,67 ; 66,67)$ & $41,66 \pm 12,66$ & $33,33(16,67 ; 83,33)$ & $43,58 \pm 19,88$ & $0,959^{\mathrm{a}}$ \\
\hline Post & $50,00(0,00 ; 83,33)$ & $44,04 \pm 23,21$ & $66,67(16,67 ; 83,33)$ & $51,28 \pm 22,00$ & $0,359^{\mathrm{a}}$ \\
\hline$p$ & $0,522^{\mathrm{c}}$ & & $0,088^{\mathrm{c}}$ & & \\
\hline \multicolumn{6}{|l|}{ Sikap } \\
\hline Pre & $68,00(48,00 ; 74,00)$ & $66,42 \pm 7,06$ & $68,00(60,00 ; 84,00)$ & $67,84 \pm 6,85$ & $1,000^{\mathrm{a}}$ \\
\hline Post & $64,00(48,00 ; 72,00)$ & $64,00 \pm 6,7$ & $68,00(56,00 ; 76,00)$ & $68,61 \pm 5,5$ & $0,063^{\mathrm{b}}$ \\
\hline$p$ & $0,073^{\mathrm{c}}$ & & $0,537^{\mathrm{d}}$ & & \\
\hline \multicolumn{6}{|l|}{ Praktik } \\
\hline Pre & $67,86(14,29 ; 100,00)$ & $65,30 \pm 28,27$ & $64,92(21,34 ; 100,00)$ & $64,29 \pm 28,71$ & $0,927^{\mathrm{b}}$ \\
\hline Post & $60,71(14,29 ; 100,00)$ & $67,34 \pm 28,53$ & $57,14(14,29 ; 100,00)$ & $62,08 \pm 26,46$ & $0,692^{\mathrm{a}}$ \\
\hline$p$ & $0,073^{\mathrm{c}}$ & & $0,527^{\mathrm{d}}$ & & \\
\hline
\end{tabular}

Tabel 3 Perbedaan Perubahan Nilai Pengetahuan, Sikap dan Praktik Konsumsi Sayur dan Buah

\begin{tabular}{lccccc}
\hline \multicolumn{1}{c}{ Perubahan } & \multicolumn{2}{c}{ Booklet $(\mathbf{n = 1 4})$} & \multicolumn{2}{c}{ Ceramah $(\mathbf{n}=13)$} & $\boldsymbol{p}$ \\
\cline { 2 - 6 } \multicolumn{1}{c}{ Nilai $(\Delta)$} & Median $($ Min; Max) & Rerata \pm SD & Median $($ Min; Max) & Rerata \pm SD & \\
\hline Pengetahuan & $0,00(-33,33 ; 33,33)$ & 2,38 & $0,00(-16,67 ; 33,34)$ & 7,69 & $0,415^{\mathrm{a}}$ \\
Sikap & $-4,00(-16,00 ; 24,00)$ & $-2,42$ & $0,00(-8,00 ; 8,00)$ & 0,76 & $0,028^{\mathrm{b}}$ \\
Praktik & $0,00(-42,86 ; 42,86)$ & 2,04 & $0,00(-25,71 ; 14,28)$ & $-2,19$ & $0,546^{\mathrm{b}}$ \\
\hline
\end{tabular}

${ }^{\mathrm{a}}$ Independent T-test; ${ }^{\mathrm{b}}$ Mann-Whitney

Tabel 4 Gambaran Kategori Pengetahuan, Sikap dan Praktik Konsumsi Sayur dan Buah

\begin{tabular}{|c|c|c|c|c|c|c|}
\hline \multirow[b]{2}{*}{ Variabel } & \multicolumn{3}{|c|}{ Booklet $(n=14)$} & \multicolumn{3}{|c|}{ Ceramah $(n=13)$} \\
\hline & $\begin{array}{c}\text { Kurang } \\
\text { n (\%) }\end{array}$ & $\begin{array}{c}\text { Cukup } \\
\text { n }(\%)\end{array}$ & $\begin{array}{c}\text { Baik } \\
\text { n (\%) }\end{array}$ & $\begin{array}{c}\text { Kurang } \\
\text { n (\%) }\end{array}$ & $\begin{array}{c}\text { Cukup } \\
\text { n }(\%)\end{array}$ & $\begin{array}{c}\text { Baik } \\
\text { n }(\%)\end{array}$ \\
\hline \multicolumn{7}{|l|}{ Pengetahuan } \\
\hline Pre & $13(93 \%)$ & $1(7 \%)$ & - & $10(77 \%)$ & $2(15 \%)$ & $1(8 \%)$ \\
\hline Post & $12(86 \%)$ & - & $2(14 \%)$ & $6(46 \%)$ & $6(46 \%)$ & $1(8 \%)$ \\
\hline \multicolumn{7}{|l|}{ Sikap } \\
\hline Pre & $2(14 \%)$ & $12(86 \%)$ & - & - & $12(92 \%)$ & $1(8 \%)$ \\
\hline Post & $3(21 \%)$ & $11(79 \%)$ & - & $1(8 \%)$ & $12(92 \%)$ & - \\
\hline \multicolumn{7}{|l|}{ Praktik } \\
\hline Pre & $11(79 \%)$ & $3(21 \%)$ & & $9(69 \%)$ & $4(31 \%)$ & \\
\hline Post & $9(64 \%)$ & $5(36 \%)$ & & $10(77 \%)$ & $3(23 \%)$ & \\
\hline
\end{tabular}

Tabel 2, hasil analisis data sebelum edukasi menunjukkan tidak terdapat perbedaan pengetahuan $(p=0,959)$, sikap $(p=1,000)$, dan praktik konsumsi sayur dan buah $(p=0,927)$ antara kedua kelompok perlakuan sebelum edukasi. Setelah edukasi, juga tidak ada beda pengetahuan $(p=0,359)$, sikap $(p=0,063)$, dan praktik konsumsi sayur dan buah $(p=0,692)$ antara kedua kelompok perlakuan. Nilai pengetahuan dan sikap, setelah edukasi, lebih tinggi pada kelompok ceramah. Sebaliknya, nilai praktik konsumsi sayur dan buah, setelah edukasi, lebih tinggi pada kelompok booklet.
Nilai pengetahuan meningkat pada kelompok booklet maupun ceramah. Namun, secara statistik tidak ada beda pengetahuan antara sebelum dan sesudah edukasi pada kelompok booklet $(p=0,522)$ maupun ceramah $(p=0,088)$. Analisis data sikap menunjukkan tidak ada beda sikap antara sebelum dan sesudah edukasi pada kelompok booklet $(p=0,073)$ maupun ceramah $(p=0,537)$. Nilai sikap pada kelompok booklet mengalami penurunan. Tidak ada beda nilai praktik konsumsi sayur dan buah antara sebelum dan sesudah edukasi, baik pada kelompok ceramah $(p=0,073)$ ataupun kelompok booklet $(p=0,527)$. Nilai praktik konsumsi sayur dan 
buah pada kelompok ceramah mengalami penurunan.

Tabel 3 menunjukkan tidak terdapat perbedaan perubahan pengetahuan $(p=0,415)$ dan praktik konsumsi sayur dan buah $(p=0,546)$ pada kedua kelompok perlakuan. Ada beda perubahan sikap $(p=0,028)$ pada kedua kelompok perlakuan. Perubahan $(\Delta)$ yang bernilai negatif menunjukkan beberapa subjek penelitian yang mengalami penurunan skor pre-test ke post-test, hal ini terjadi pada sikap kelompok booklet.

Variabel pengetahuan pada kelompok booklet mengalami peningkatan dengan adanya peningkatan subjek penelitian dengan kategori pengetahuan baik, sebagaimana pada kelompok ceramah terjadi pergeseran positif dari subjek penelitian dengan kategori pengetahuan kurang menjadi kategori cukup. Variabel sikap mengalami penurunan dengan bertambahnya jumlah subjek penelitian dengan kategori sikap kurang pada kelompok booklet maupun ceramah. Kecenderungan yang sama terjadi pada variabel praktik, dimana subjek penelitian dengan kategori praktik kurang bertambah pada kelompok ceramah. Namun, pada kelompok booklet terjadi peningkatan subjek penelitian dengan kategori praktik baik.

\section{PEMBAHASAN}

Remaja merupakan bagian populasi yang rentan terhadap masalah gizi. ${ }^{13}$ Pemenuhan zat gizi yang tidak adekuat pada remaja menyebabkan masalah gizi, diantaranya gizi kurang dan gizi lebih. ${ }^{14}$ Data pada penelitian ini menunjukkan adanya permasalahan gizi yang terjadi pada remaja Tuli di SMPLB dan SMALB di kota Semarang. Prevalensi kurus sebesar $18,51 \%$, gemuk sebesar $11,11 \%$, dan obesitas sebesar $14,81 \%$ pada subjek penelitian dari kedua kelompok. Hal ini sejalan dengan penelitian di Jimbaran tahun 2014, bahwa $20 \%$ siswa SLB B berstatus gizi kurus. ${ }^{4}$ Prevalensi gemuk dan obesitas lebih besar dibandingkan prevalensi kurus. Hasil RISKESDAS 2018 menunjukkan kecenderungan yang sama, bahwa masalah gizi pada remaja usia 13 - 15 tahun dan 1618 tahun lebih didominasi oleh masalah gizi lebih dibandingkan masalah gizi kurang. ${ }^{2}$ Permasalahan gizi terjadi pada seluruh lapisan masyarakat remaja, termasuk remaja berkebutuhan khusus.

Subjek penelitian pada kelompok ceramah dan booklet memiliki karakteristik pengetahuan, sikap dan praktik konsumsi sayur dan buah yang sama sebelum pemberian edukasi gizi. Persamaan karakteristik umum pada kedua kelompok perlakuan menjadi faktor yang berpengaruh. ${ }^{15,16}$ Data penelitian ini menunjukkan bahwa mayoritas pengetahuan subjek penelitian berada pada tingkat kurang sebelum pemberian edukasi gizi. Mayoritas sikap subjek penelitian berada pada tingkat cukup walaupun mayoritas berpengetahuan kurang. Penelitian lain dengan subjek remaja Dengar menunjukkan hal yang berlawanan bahwa mayoritas remaja SMA memiliki pengetahuan gizi dan sikap gizi cukup ataupun baik. ${ }^{6}$ Umumnya pengalaman edukasi gizi memiliki dampak positif pada pengetahuan gizi. ${ }^{16}$ Bertolak belakang dengan fakta tersebut, penelitian ini menunjukkan besarnya persentase subjek penelitian yang pernah mendapatkan edukasi gizi $( \pm 80 \%)$ tidak menimbulkan dampak positif terhadap tingkat pengetahuan gizi subjek penelitian.

Pengetahuan subjek penelitian dikatakan tidak berubah karena terjadi peningkatan tetapi tidak bermakna pada kedua kelompok perlakuan. Hal ini diduga karena metode ceramah maupun booklet belum optimal diterapkan pada subjek penelitian yang Tuli. Metode ceramah belum optimal diterapkan pada Tuli karena dilakukan hanya dengan frekuensi satu kali. Tuli memiliki kesulitan dalam mencerna materi yang sifatnya abstrak, sehingga memerlukan waktu yang lebih lama hingga mencapai titik paham. Frekuensi pertemuan yang lebih sering juga memberi kesempatan Tuli untuk mendapatkan repetisi materi. Lebih sering materi diulang akan membuat Tuli memahami dengan lebih baik dan menyeluruh. Metode booklet belum optimal karena subjek penelitian tidak memiliki cukup pengetahuan dasar. Kecukupan pengetahuan dasar membantu Tuli mengaplikasikan teknik visualmatching saat membaca booklet. Teknik visualmatching adalah cara yang sering digunakan oleh Tuli untuk memahami bahan bacaan, yaitu teknik menyesuaikan tulisan dengan gambar yang ada. Hal ini membantu Tuli, yang memiliki sedikit perbendaharaan kata, untuk mempersepsikan isi bacaan secara mandiri. ${ }^{17}$ Data penelitian ini menunjukkan mayoritas memiliki tingkat pengetahuan yang kurang sebelum edukasi gizi. Hal ini memunculkan dugaan bahwa subjek penelitian masih cukup kesulitan memahami isi booklet walaupun teknik visual-matching telah diterapkan.

Hasil penelitian ini bertolak belakang dengan penelitian sebelumnya, yaitu terdapat peningkatan rerata pengetahuan yang bermakna sebelum dan setelah edukasi gizi melalui metode booklet maupun metode ceramah. ${ }^{6}$ Metodologi yang digunakan dalam penelitian tersebut sama dengan penelitian ini dalam hal metode penyampaian, frekuensi edukasi, jarak pengambilan data pre-post dan daur usia subjek, tapi beda pada status gizi dan kemampuan komunikasi yaitu overweight dan Tuli. Orang dengan status gizi lebih cenderung lebih terobsesi dan lebih hati-hati terhadap dietnya, diduga 
mereka lebih fokus menyimak edukasi. ${ }^{18}$ Mayoritas subjek pada penelitian ini berstatus gizi normal. Sedikitnya subjek yang mengajukan pertanyaan dan melamun saat edukasi berlangsung dianggap sebagai tanda kurang fokus subjek penelitian dalam menyimak materi. Perbedaan kemampuan komunikasi pada Tuli memiliki pengaruh terhadap fungsi kognitif terkait bahasa yang kemudian memengaruhi proses Tuli dalam memutuskan jawaban suatu pertanyaan. ${ }^{19}$ Banyaknya kosakata baru yang asing bagi Tuli diduga menjadi kesulitan tersendiri. ${ }^{8}$ Kosakata terkait zat gizi adalah salah satu kosakata baru yang asing dan sulit dipahami oleh subjek penelitian, sehingga harus dijelaskan secara baik melalui definisi dan contoh.

Peningkatan pengetahuan pada kelompok ceramah lebih tinggi dibandingkan kelompok booklet ditinjau dari nilai median. Penjelasan langsung (lip-reading) bersama dengan bantuan isyarat dapat membantu Tuli untuk lebih memahami informasi yang diberikan secara menyeluruh. ${ }^{20}$ Metode ceramah memberi kesempatan penceramah untuk lebih cepat menangkap bagian materi yang perlu diulang dengan membaca ekspresi subjek penelitian. Saat membaca booklet, ekspresi subjek penelitian cenderung tidak terbaca. Keberadaan juru bahasa isyarat juga sebagai pengingat apabila pemateri terlalu cepat atau kurang jelas dalam menyampaikan materi.

Kemampuan berpikir kritis subjek penelitian memengaruhi kualitas pengisian kuesioner pengetahuan. Pertanyaan dengan model hafalan lebih mudah untuk dijawab dibandingkan pertanyaan terkait manfaat yang membutuhkan ketelitian lebih dalam memilih jawaban. Hal ini diduga sebagai salah satu imbas seringnya Tuli mendapatkan informasi yang sifatnya sempit tanpa diberikan penjelasan, sehingga terbentuk cara berpikir yang terlalu sederhana. ${ }^{21}$ Selain itu kurikulum pendidikan khusus dinilai masih memerlukan pengembangan untuk mencapai kemampuan berpikir kritis dan memecahkan masalah pada siswa. ${ }^{22}$

Sikap subjek penelitian cenderung tidak berubah karena kepercayaan antara edukator dan subjek penelitian belum terbangun optimal. Membangun kepercayaan sebelum edukasi gizi dilakukan merupakan hal yang sangat penting. ${ }^{23} \mathrm{Di}$ sisi lain Tuli diduga memiliki kecenderungan merasa canggung untuk menghadapi situasi sosial yang baru seperti berinteraksi dengan orang Dengar yang baru dikenal. $^{23,24}$ Tuli memiliki karakteristik emosional, mental dan sosial yang berbeda. ${ }^{22}$ Subjek penelitian disini cenderung pemalu dan tertutup pada saat pertemuan pertama, tapi menjadi lebih aktif saat pertemuan selanjutnya dan saat berkomunikasi melalui sosial media. Oleh karena itu, menjadi penting untuk mengadakan kegiatan pre-edukasi gizi agar terbangun kepercayaan dan kenyamanan di awal. Kepercayaan antara edukator dan subjek penelitian juga dapat diperkuat dengan interaksi langsung tanpa ada pihak ketiga, sehingga akan lebih optimal jika edukasi gizi didukung oleh pemateri yang menguasai bahasa isyarat dengan fasih tanpa bantuan juru bahasa isyarat. Selain itu, tidak terjadinya perubahan sikap juga dipengaruhi oleh durasi program yang terlalu pendek. Kecenderungan pada penelitian lainnya menunjukkan, bahwa perubahan sikap seseorang membutuhkan waktu lebih dari 1 minggu proses intervensi. ${ }^{25,26}$

Praktik konsumsi sayur dan buah yang cenderung tidak berubah dipengaruhi oleh banyak faktor. Sikap terletak pada posisi sentral dalam kaitannya dengan praktik atau tindakan manusia. ${ }^{27}$ Tidak ada perubahan sikap pada penelitian ini menyebabkan praktik konsumsi sayur dan buah tidak mengalami perubahan. Penelitian sebelumnya pada subjek berkarakter serupa dengan edukasi gizi metode booklet menunjukkan tidak ada beda praktik gizi antara sebelum dan sesudah pemberian edukasi. ${ }^{25}$ Namun, terjadi perubahan praktik gizi pada kelompok dengan metode edukasi yang lebih interaktif. Subjek penelitian merupakan remaja berkebutuhan khusus sehingga dibutuhkan program yang lebih interaktif dan inklusif. Selama program edukasi gizi pada penelitian ini berlangsung, tidak banyak subjek penelitian yang mampu mengekspresikan pemikirannya dan pemateri masih sulit memahami keadaan subjek. Program yang interaktif membuat subjek penelitian lebih memahami materi yang diberikan, sehingga terjadi peningkatan pengetahuan. Pengetahuan yang baik akan berimbas pada peningkatan sikap sebagai salah satu faktor yang memengaruhi praktik. ${ }^{25}$

Pemberian lembar kerja "Buku Harian Sayur dan Buah" pada kelompok booklet memberikan pengaruh positif terhadap praktik konsumsi sayur dan buah. Lembar kerja pada penelitian ini diberikan sebagai stimulus agar subjek penelitian memiliki motivasi untuk membaca ulang materi dan motivasi mengonsumsi sayur dan buah. Hal ini sejalan dengan penelitian sebelumnya, yaitu pemberian pekerjaan rumah dalam bentuk Food Diary secara signifikan mampu meningkatkan konsumsi sayuran pada akhir pekan. Cara ini memberikan dampak karena memuat tugas yang sifatnya aplikatif, terkait dengan kehidupan sehari-hari dan mempermudah pengajar dalam menyampaikan materi terkait kesehatan. ${ }^{28}$ Subjek penelitian pada kelompok ceramah memiliki nilai praktik yang lebih rendah. Hal ini diduga karena tidak diberikan tugas untuk mengisi lembar kerja "Buku Harian Sayur dan 
Buah" atau tindakan lanjutan serupa lainnya, sehingga tidak merasa ada motivasi tambahan untuk mengonsumsi sayur dan buah.

Faktor kontrol eksternal yang tidak ada pada penelitian seperti tingkat pendapatan keluarga dan ketersediaan makanan kemungkinan memiliki pengaruh terhadap praktik konsumsi sayur dan buah. Tingkat pendapatan keluarga mencerminkan kemampuan daya beli bahan makanan di tingkat rumah tangga. ${ }^{29}$ Tingkat pendapatan orang tua subjek penelitian sangat beragam, mulai dari menengah hingga atas. Remaja dimungkinkan memiliki keterbatasan dalam pemilihan makanan oleh dirinya sendiri, sehingga faktor lingkungan seperti ketersediaan sayur dan buah dapat secara langsung berpengaruh pada praktiknya. ${ }^{30}$ Ketersediaan sayur dan buah di rumah dan sekolah berhubungan positif dengan konsumsi sayur dan buah pada remaja. ${ }^{31}$ Ketersediaan sayur di sekolah terbatas hanya pada menu makanan di kantin sekolah dan tidak tersedianya buah di sekolah kecuali pada kegiatan tertentu.

Faktor emosi, lucky guessing dan bluff adalah beberapa hal yang diduga memengaruhi subjek penelitian dalam mengisi kuesioner, sehingga menyebabkan beberapa subjek penelitian mengalami penurunan pada nilai sikap ataupun praktik. Emosi bersifat sementara, sehingga sikap yang terbentuk akibat dominansi emosi akan bersifat sementara dan akan berlalu saat keadaan emosi kembali normal. ${ }^{32}$ Rasa cemas dan tidak percaya diri merupakan faktor internal yang menyebabkan timbulnya emosi. Tidak percaya diri dalam menjawab pertanyaan menimbulkan ketakutan menjawab salah. Hal tersebut dapat memantik ketidakjujuran dalam menjawab pertanyaan. ${ }^{33}$ Rasa kurang percaya diri di penelitian ini terlihat dari beberapa subjek penelitian mencoba melihat atau bertanya jawaban teman, sudah selesai mengerjakan tapi tidak berani mengumpulkan, atau berulang kali mengganti jawaban. Selanjutnya, ada kemungkinan Tuli berpura-pura paham dengan kuesioner atau pun materi yang diberikan. Hal ini sering disebut sebagai Bluff, yaitu kondisi dimana Tuli berpura-pura paham atas materi yang disampaikan lawan bicara. Bluff, salah satunya, disebabkan Tuli merasa tidak nyaman jika harus minta materi diulang terus-menerus. ${ }^{34,35}$ Faktor keberuntungan menerka-nerka jawaban (lucky guessing) pada saat pre-test diduga menyebabkan nilai yang diperoleh subjek penelitian menjadi tidak mencerminkan yang sebenarnya, ini menjadi keterbatasan dalam penelitian ini. ${ }^{33}$

Kedua metode edukasi diduga belum mampu membangun suasana yang interaktif. Kegiatan yang interaktif dapat membangun atensi dan keaktifan subjek penelitian. ${ }^{36}$ Kegiatan interaktif membantu Tuli lebih mudah dalam mengaplikasikan teori pada kehidupan sehari-hari. ${ }^{24}$ Penelitian ini menggunakan kegiatan tanya-jawab sebagai pemantik keaktifan subjek penelitian. Namun, kegiatan tanya-jawab di sini dirasa belum cukup menarik peserta untuk secara aktif masuk ke dalam pembelajaran. Hanya beberapa subjek penelitian yang memperlihatkan antusiasme dan memberikan pertanyaan.

Optimalisasi metode ceramah dan booklet perlu dilakukan dengan modifikasi pada beberapa aspek. Metode booklet dapat dioptimalkan dengan pembentukan peer group discussion dengan fasilitator yang berasal dari kalangan siswa Tuli sendiri akan menambah kemudahan Tuli untuk memahami kosakata yang asing. Penempatan fasilitator siswa Tuli dalam suatu kelompok diskusi membuat pemateri terbantu dalam menjelaskan materi. Fasilitator dipilih dari kemampuan komunikasi yang lebih baik diantara temantemannya dan akan menerima pelatihan terlebih dahulu, sehingga saat edukasi berjalan lebih paham tindakan yang harus dilakukan dan terlebih dahulu memahami materi edukasi disbanding temantemannya. Fasilitator akan menyampaikan pertanyaan atau kebingungan siswa lainnya dengan cara yang lebih dekat dan mudah dipahami. ${ }^{37}$ Metode ceramah akan lebih baik jika dilakukan dengan penguatan kemampuan berbahasa isyarat dari penceramah. Pemberian ceramah berbasis bahasa isyarat yang langsung dilakukan oleh penceramah, tanpa bantuan juru bahasa isyarat, akan mempermudah Tuli untuk membagi fokus pandangan. Penelitian sebelumnya menyebutkan bahwa proses pemahaman Tuli terhadap materi akan lebih baik ketika diawali dengan mengamati petunjuk visual lalu mengamati penjelasan penceramah dengan bahasa isyarat. ${ }^{37}$ Petunjuk visual bisa diberikan melalui slide atau media lain seperti booklet. Jadi, penggabungan kedua metode, yaitu ceramah berbasis bahasa isyarat dan booklet memiliki kemungkinan menciptakan hasil yang lebih baik.

Teknologi bisa menjadi solusi lain dalam mempermudah interaksi dalam edukasi kepada Tuli, ketika ada keterbatasan waktu. Penggunaan teknologi, seperti aplikasi kuis untuk tanya jawab, akan mempermudah Tuli mengungkapkan hal-hal yang dipahami dan belum dipahami dengan yakin dan percaya diri, serta subjek penelitian tidak malu untuk mengemukakan pendapat dan pertanyaan. Penelitian sebelumnya menyebutkan bahwa bantuan aplikasi pada smartphone menutup sisi pemalu dan ragu-ragu dari Tuli dalam waktu yang lebih singkat. Teknologi membuat mereka lebih cepat untuk tampil berani dan bebas mengekspresikan pendapat. ${ }^{36}$ 
Subjek penelitian pada penelitian ini pun menunjukkan cara komunikasi yang lebih terbuka ketika berkomunikasi melalui media sosial. Bantuan teknologi memiliki kesempatan yang cukup besar untuk mewujudkan kegiatan edukasi yang lebih interaktif. Pendekatan teknologi akan menghadirkan edukasi yang dekat dengan remaja.

\section{SIMPULAN}

Tidak ada pengaruh edukasi gizi dengan metode ceramah berbasis bahasa isyarat Indonesia (BISINDO) dan booklet terhadap pengetahuan, sikap dan praktik konsumsi sayur dan buah pada remaja Tuli SLB di Semarang karena kedua metode belum cukup baik membangun suasana edukasi yang interaktif dan inklusif.

Perlu adanya pengembangan metode dan media sebagai sarana pemberian edukasi gizi pada kelompok Tuli, seperti: (1 durasi program edukasi yang perlu diperpanjang, 2) pelatihan bahasa isyarat untuk penceramah pada metode ceramah, 3) penerapan sistem peer group discussion pada kelompok booklet dengan fasilitator yang berasal dari kalangan siswa Tuli sendiri, sehingga tercipta program edukasi gizi yang lebih interaktif dan inklusif untuk Tuli.

\section{DAFTAR PUSTAKA}

1. Salam RA, Hooda M, Das JK, Arshad A, Lassi ZS, Middleton P, et al. Interventions to Improve Adolescent Nutrition: A Systematic Review and Meta-Analysis. Journal of Adolescent Health 2016;59(2):S29-39.

2. Kementerian Kesehatan RI. Laporan Nasional RISKESDAS 2018. Jakarta; 2019.

3. Kementerian Kesehatan RI. Perilaku Berisiko Kesehatan pada Pelajar SMP dan SMA di Indonesia. Jakarta; 2015.

4. Putra IKAS, Adhi KT. Status Gizi Penyandang Cacat ( Tunagrahita dan Tunarungu ) di sekolah luar biasa B negeri Pembina Tingkat Nasional Kelurahan Jimbaran Kabupaten Badung. Community Heatlh. 2014;II(1):32-41.

5. Maulana HDJ. Promosi Kesehatan. Yudha EK, editor. Jakarta: Penerbit Buku Kedokteran EGC; 2009.

6. Safitri NRD, Fitranti DY. Pengaruh Edukasi Gizi dengan Ceramah dan Booklet terhadap Peningkatan Pengetahuan dan Sikap Gizi Remaja Overweight. Journal of Nutrition College. 2016;6(Jilid 2):277-84.

7. Baldasso JG, Galante AP, De Piano Ganen A. Impact of actions of food and nutrition education program in a population of adolescents. Revista de Nutricao. 2016;29(1):65-75.
8. Widia YA. Pemerolehan Kosakata Anak Tunarungu berdasarkan Kelas Kata Bahasa Indonesia di SDLB Karya Mulia II Surabaya: Kajian Psikolinguistik. Skriptorium. 2012;1(2):129-42.

9. Worsfold S, Mahon M, Pimperton H, Stevenson J, Kennedy C. Predicting reading ability in teenagers who are deaf or hard of hearing: A longitudinal analysis of language and reading. Research of Development Disabilities. 2018;77(February):49-59.

10. Hartono NP, Wilujeng CS, Andarini S. Pendidikan Gizi tentang Pengetahuan Pemilihan Jajajan Sehat antara Metode Ceramah dan Metode Komik. Indonesian Journal of Human Nutrition. 2015;1(2):135-48.

11. Kuenburg A, Fellinger P, Fellinger J. Health Care Access Among Deaf People. Journal of Deaf Studies and Deaf Education. 2016;21(1):1-10.

12. SignHealth. Sick of It: How the Health Service Is Failing Deaf People [Internet]. 2014. Available from: www.signhealth.org.uk

13. Deka MK, Malhotra AK, Yadav R, Gupta S. Dietary Pattern and Nutritional Deficiencies Among Urban Adolescents. Journal of Family Medicine and Primary Care. 2015;4(3):364-8.

14. Susetyowati. "Gizi Remaja" dalam Ilmu Gizi : Teori dan Aplikasi. Jakarta: Penerbit Buku Kedokteran EGC; 2017. p. 160-9.

15. Grunert KG, Wills J, Celemín LF, Lähteenmäki L, Scholderer J, Storcksdieck genannt Bonsmann S. Socio-demographic and Attitudinal Determinants of Nutrition Knowledge of Food Shoppers in Six European Countries. Food Quality and Preference. 2012;26(2):166-77.

16. Philippou E, Middleton N, Pistos C, Andreou E, Petrou M. The Impact of Nutrition Education on Nutrition Knowledge and Adherence to The Mediterranean Diet in Adolescent Competitive Swimmers. Journal of Science and Medicine in Sport. 2017;20(4):328-32.

17. Benedict KM, Rivera MC, Antia SD. Instruction in Metacognitive Strategies to Increase Deaf and Hard-of-Hearing Students' Reading Comprehension. Journal of Deaf Studies and Deaf Education. 2018;(July):1-15.

18. Psouni S, Hassandra M, Theodorakis $\mathrm{Y}$. Exercise and Healthy Eating Intentions and Behaviors among Normal Weight and Overweight / Obese Adults. Psychology. 2016;7:598-611.

19. Bin X, Peng L, Aiqing Z, Liping Y. DecisionMaking in Adolescents with Profound Hearing Loss. Journal of Deaf Studies and Deaf 
Education. 2018;23(3):219-27.

20. Cawthon SW. Teaching Strategies in Inclusive Classrooms With Deaf Students. Journal of Deaf Studies and Deaf Education. 2001;6(3):212-25.

21. Jones AC, Gutierrez R, Ludlow AK. Confronting the Language Barrier: Theory of Mind in Deaf Children. Journal of Communication Disorders. 2015;56:47-58.

22. Sutjipto. Pandangan Guru dalam Pengembangan Kurikulum Pendidikan Khusus. Jurnal Pendidikan dan Kebudayaan. 2018;3(1):73-98.

23. Ghari Z. The Cognitive, Psychological and Cultural Impact of Communication Barrier on Deaf Adults' Content of Speech in Iran. Journal of Communcation Disorders, Deaf Studies and Hearing Aids. 2016;4:164.

24. Mohanraj B, Sevalraj I. Psychological Issues Among Hearing Impaired Adolescents. Education Science and Psychology. 2013;2(24).

25. Roszanadia R, Norazmir MN. Knowledge, Attitude and Practice on Healthy Eating among Special Needs Boarding School Students. International Journal of Dairy Science. 2011;6(5):278-86.

26. Rani MA, Shriraam V, Zachariah R, Harries AD, Satyanarayana S, Tetali S, et al. Does A Nutrition Education Program Change The Knowledge and Practice of Healthy Diets among High School Adolescent in Chennai India? Health Education Journal. 2012.

27. Machrus HUP. Behavioral Measurement based on Theory of Planned Behaviour. Insan Media Psikologi. 2010;12(01):64-72.

28. Duncan S, Mcphee JC, Schluter PJ, Zinn C, Smith R, Schofield G. Efficacy of a Compulsory Homework Programme for Increasing Physical Activity and Healthy Eating in Children: The Healthy Homework Pilot Study. International Journal of Behavioral Nutrition and Physical Activity. 2011;8(1):127.

29. Rachman BN, Mustika IG, Kusumawati IGAW. Faktor yang Berhubungan dengan Perilaku Konsumsi Buah dan Sayur Siswa SMP di Denpasar. Jurnal Gizi Indonesia. 2017;6(1).

30. Klepp KI. Promoting Fruit and Vegetable Consumption among European Schoolchildren: Rationale, Conceptualization and Design of the Pro Children Project. Annals of Nutrition and Metabolism. 2005;49:212-20.

31. Noia J Di, Contento IR. Fruit and Vegetable Enables Adolescent Consumption that Exceeds National Average. Nutrition Research. 2010;30:396-402.

32. Azwar S. 2011. Sikap Manusia. Edisi ke-2. Yogyakarta: Pustaka Pelajar.

33. Domnich A, Panatto D, Gasparini R. Uncontrolled Web-Based Administration of Surveys on Factual Health-Related Knowledge: A Randomized Study of Untimed Versus Timed Quizzing. J Med Internet Res. 2015;17(4).

34. Vandenhoff S. Does Hearing Loss Affect Introverts and Extroverts Differently? [Internet]Hearing Education and Rehabilitation for Adults. 2011.

35. Vandenhoff S. Are You Bluffing? [Intenet] Hearing Education and Rehabilitation for Adults. 2011.

36. Meguid EA, Collins M. Students' Perceptions of Lecturing Approaches: Traditional Versus Interactive Teaching. Advances in Medical Education and Practice. 2017;8:229-41.

37. Herring-Harrison TJ, Gardner R, Lovelace TS. Adapting peer tutoring for learners who are deaf or hard of hearing. Intervention in School and Clinic. 2007;43(2):82-7. 